\title{
PHySiCAL OCEANOGRAPHY OF THE SOUTHWEST ATLANTIC OCEAN
}

By Edmo J.D. Campos, Jerry L. Miller, Thomas J. Müller and Ray G. Peterson

$\mathrm{F}$ ROM ITS LITTORAL margin to the open ocean, the western South Atlantic (Fig. 1) is marked at all depths by circulation patterns and exchange processes that are centrally important to the regional marine resources and local economies, and to the global flux of heat and dissolved substances. Among other important characteristics, the Southwest Atlantic (SWA) is characterized by the presence of the Brazil Current (BC), a warm western boundary current that, while weaker than the Gulf Stream in terms of mass transport, is energetically comparable to its North Atlantic counterpart, particularly in the region of confluence with the northward-flowing Malvinas Current (MC) at approximately $38^{\circ} \mathrm{S}$. Because of the wide range of issues needed to be understood in terms of the physical oceanography, this oceanic region has been addressed by several important scientific programs, a few of which are listed in Table 1 and indicated on Fig. 2. Results from these and other programs are summarized here and recommendations for future efforts are offered.

\section{Basic Patterns of Circulation}

Inshore from the northern Brazil Current, over a continental shelf that widens gradually toward the south, are regions where seasonal wind-driven upwelling of cold, nutrient-rich waters occurs. These are important elements of the shelf circulation and they have major impacts on biological productivity. In particular, the Cabo Frio region (Fig. 1) has long been known for its active windinduced upwelling, and new measurements from surface drifters now show that a counter-circulation exists on the shelf in the Santos Bight inshore of the Brazil Current (Stevenson and de Souza, 1994). Occasionally, this may be associated with

Edmo J.D. Campos, Instituto Oceanográfico, Universidade de São Paulo, 05508-900 São Paulo. Brazil. Jerry L. Miller, Center for Coastal Physical Oceanography. Old Dominion University. Norfolk. Virginia 23529, USA. Thomas J. Müller, Institut für Meereskunde, Universität Kiel, 24105 Kiel, Germany. Ray G. Peterson, Scripps Institution of Oceanography, University of California-San Diego, La Jolla, California 92093-0230, USA. the northern end of a cold and fresh shelf current that originates on the Argentine shelf (Piola, 1994; E.J.D. Campos, unpublished observations). Not much is known about this shelf current, whose source waters may derive ultimately from the shelf region of the northern Drake Passage. These waters are apparently modified by surface heat fluxes over the Argentine shelf and by discharge at $35^{\circ} \mathrm{S}$ from the Rio de la Plata estuary. They may represent a major conduit for exchange not only of heat and salt, but also of nutrients and biota, the latter having significant economic importance. All along the shelf, surface heat fluxes drive large variations in the density field at seasonal and higher frequencies, leading to cycles of stratification and destratification. These variations in static stability in turn produce circulation patterns that alter the transport of nutrients and biological materials.

Adjacent to the northern shelf circulation is the Brazil Current, which has its origins in the southern portion of the southernmost of three branches of the South Equatorial Current (Stramma et al., 1990; da Silveira et al., 1994). The initial transport of the Brazil Current is just 2-4 Sv (Stramma et al., 1990) and it remains small, $\leq 5 \mathrm{~Sv}$, for more than $1,000 \mathrm{~km}$, while being confined to the upper continental slope and shelf edge (Peterson and Stramma, 1991). Just beyond the shelf break and offshore from the northern Brazil Current, at depths of 800-1,000 $\mathrm{m}$ is the northward flow of Antarctic Intermediate Water (AAIW) (Reid, 1989). Beneath this is the northward flow of the Upper Circumpolar Deep Water (UCDW), then the southward-flowing North Atlantic Deep Water (NADW), and finally the northward flow of the Lower Circumpolar Deep Water (LCDW). This deepest layer is also referred to as Antarctic Bottom Water (AABW). All of these western boundary currents, at their respective depths, are the critical South Atlantic links in the global transfers of heat, salt, and secondary constituents.

A major change in the flow patterns along the western boundary occurs in the southern Brazil Basin. It is becoming increasingly clear that the
. . along the shelf, surface heat fluxes drive large variations in the density field at seasonal and higher frequencies . . . 
Table 1

A partial list of national and international programs in the Southwest Atlantic

Argentine Programs: Study of the Dynamics of the Brazil-Malvinas Front Slope Fronts off Patagonia

Project COROAS (Circulação Oceânica na Região Oeste do Atlântico Sul or Oceanic Circulation in the Western Region of the South Atlantic)

Uruguayan Programs: Monitoring and Prediction of Hydro and Meteorological Conditions in Marsden Square 413

WOCE Programs:

Deep Basin Experiment

Hydrographic Program

Surface Velocity Program

Float Program

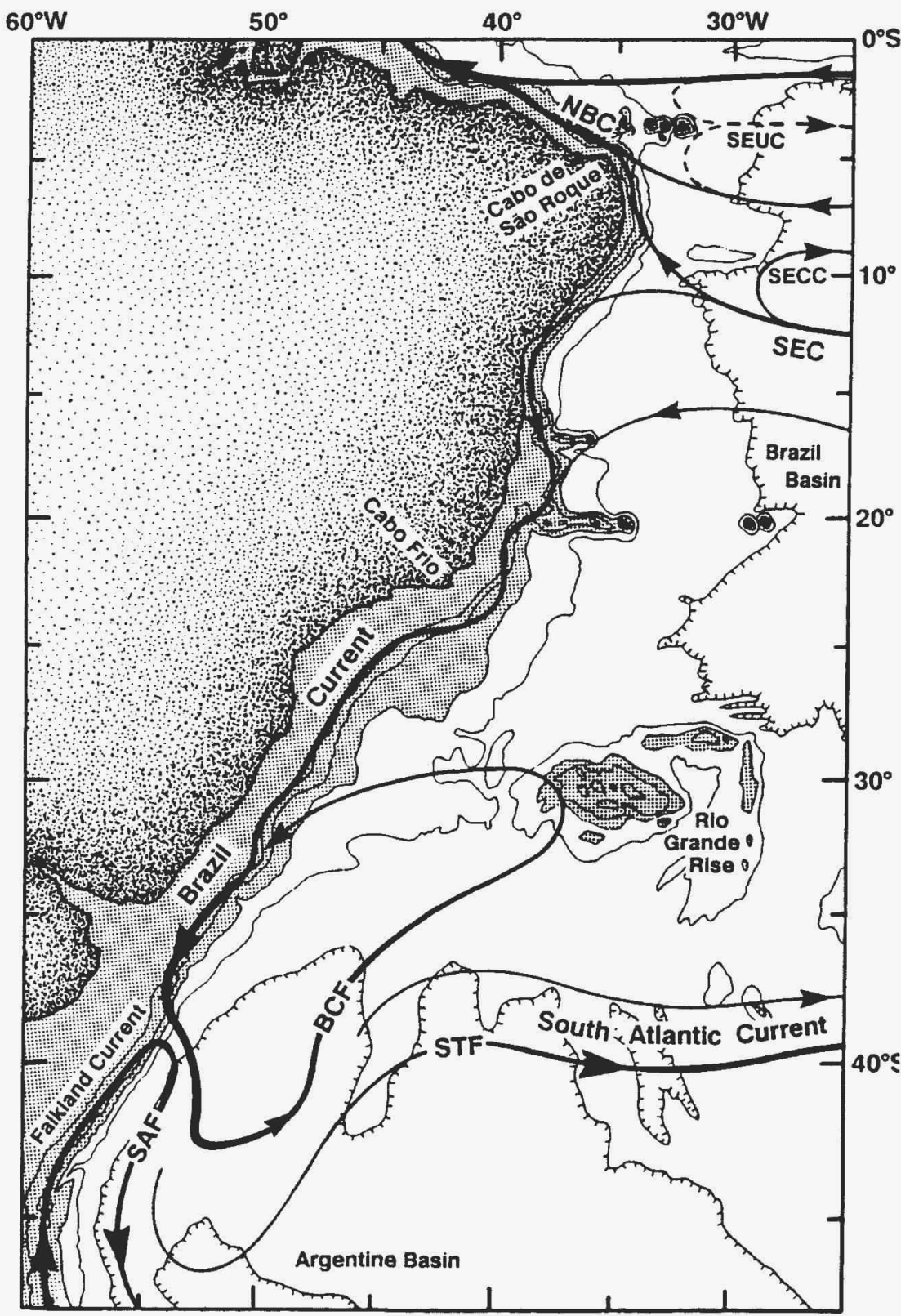

Fig. 1: Schematic of flow in the South West Atlantic. At midlatitudes are the Brazil and Falkland (or Malvinas) Currents along the western boundary and the South Atlantic Current in the interior. Near the equator, the North Brazil Current (NBC), the South Equatorial Current (SEC), the South Equatorial Countercurrent (SECC), and the South Equatorial Undercurrent (SEUC) are indicated. The contour interval is $1,000 \mathrm{~m}$.
AAIW, approaching the continental margin from the east, bifurcates into northward and southward moving components near $28^{\circ} \mathrm{S}$, though the exact place and its variability are not yet known (Müller, 1994). Similarly, the UCDW probably bifurcates at around $30^{\circ}-32^{\circ} \mathrm{S}$ (Reid, 1989). A major consequence is that the flow along the western boundary of the northern Argentine Basin, seaward of the continental shelf, is uniformly southward from the sea surface down through the AAIW, UCDW, and NADW; the deeper abyssal flow is believed to be northward. Contributing further to the southward flow in the layers above the base of the NADW is a recirculation cell in the subtropical gyre within the western Argentine Basin (Gordon and Greengrove, 1986; Stramma, 1989). The western limb of the recirculation cell separates from the continental slope at about $38^{\circ} \mathrm{S}$ upon its confluence with the northward-moving Malvinas Current, whereupon the bulk of the Malvinas retroflects cyclonically back toward the south while lesser portions continue north along the inner portions of the shelf. On the eastern side of the cyclonic trough is the combined southward flow of Malvinas and Brazil Current waters that extend to about $45^{\circ} \mathrm{S}$ before the subtropical waters turn east and north to form the poleward limits of the subtropical gyre. The Malvinas waters continue south to the southern margin of the Argentine Basin $\left(49^{\circ} \mathrm{S}\right)$ before turning east with the circumpolar regime (Peterson and Whitworth, 1989).

There is compelling evidence that in the domain of the western boundary at $35-38^{\circ} \mathrm{S}$ the total southward flow from the sea surface to depths of 3,000 $\mathrm{m}$ is on the order of 60-70 Sv (Zemba, 1991; Peterson, 1992). However, many important aspects of this deep-reaching flow and of the adjacent recirculation cell are little known. These include interactions of shelf waters with the Brazil Current, alterations of water mass characteristics at all depths through the region, and the seasonal formation of subtropical mode waters in the southeastern extension of the subtropical gyre that ventilate the thermocline farther north (Gordon, 1981). Furthermore, the large southward transport in the region may be a critical factor contributing to the production of warm-core eddies from the poleward extension of the Brazil Current. It is known that eddies are regularly spawned there, but little is known about their impact on global property distributions. These eddies can be large, up to $300-400 \mathrm{~km}$ across, and they carry heat and salt to the northern realm of the Antarctic Circumpolar Current. It is likely that they represent an important transfer mechanism, but to what extent is not known. Their impact on the heat and property balances of the Southern Ocean must be studied and understood.

Another important transfer mechanism of relatively cold and fresh water from the Southern Ocean to the more northerly circulation regimes, appears to be the cross-frontal movement of water masses in the Brazil-Malvinas Confluence Zone. 
The northward flow along the western boundary of the southern Argentine Basin is unidirectional from the surface to the seafloor, and the total volume transport appears to be $\sim 70 \mathrm{~Sv}$ at $42^{\circ} \mathrm{S}$, perhaps larger at $46^{\circ} \mathrm{S}$ deriving from another recirculation cell (Peterson, 1992). Unlike the surface waters of the Malvinas Current, which either continue to flow north on the continental shelf or turn sharply back toward the south upon their confluence with the Brazil Current, the underlying waters appear to surge eastward from the confluence zone into the central Argentine Basin north of the main flow of the Antarctic Circumpolar Current (Peterson, 1994). The loss of AAIW and UCDW from the circumpolar flow in this region may be an important part of the global thermohaline circulation.

Of additional importance are processes occurring between the inshore edge of the Malvinas Current and the outer edge of the shelf waters. A narrow band of high chlorophyll content is found there and during spring and fall it can extend more than $1,000 \mathrm{~km}$ north (Piola, 1994). Why it should be so concentrated, why it does not occur in the high-nutrient core of the Malvinas Current, and how it affects the biology of the shelf locally and farther north are completely unknown.

\section{Recommendations}

During the week of 28 November through 2 December 1994, a workshop was held at the Oceanographic Institute of the University of São Paulo, Brazil, with the purpose of discussing matters related to the physical oceanography of the Southwest Atlantic. In this workshop, the South West Atlantic Program (SWAP) working group was created, and it formulated several recommendations for future work in the region shown in Fig. 2. Attention was given to the overall scientific importance of the subject and to the likelihood of scientific payoff within the next few years. The main issues that should be addressed in the near future are given here from three perspectives. These range in scope from mesoscale shelf processes to large-scale shelf dynamics and to issues concerning the deep ocean. There are overlaps between the perspectives that will be integrated in subsequent planning to ensure that the parts of the program are well connected. The topics recommended for immediate pursuit are as follows:

1) Property exchanges due to mesoscale shelf processes

\section{a) Observational efforts}

- The first order of business is to take advantage of existing databases. Although in-situ data have been collected in various subregions (e.g., Santos Bight), none are synoptic on the large scale, and most may be aliased by mesoscale processes. Therefore, highest priority is placed on analyzing existing AVHRR and altimeter (ERS1, TOPEX/POSEIDON) data. This should provide length and time scales for variability in the various subregions and thereby provide guidance for subsequent in-situ observations.

- Recent efforts (e.g., the Brazilian project Oceanic Circulation of the Western Region of the South Atlantic-COROAS) have produced extensive maps of surface and subsurface properties associated with frontal meanders and eddies. However, it is highly likely that these are aliased due to propagation and development of the features during the cruises. Quasi-Lagrangian "feature"-following surveys should be conducted to better quantify their temporal and spatial growth/decay characteristics.

- Little is known about the low-frequency variability of the basic potential vorticity state of the Brazil and Malvinas currents. As a result, studies of instability and eddy shedding processes are purely qualitative.

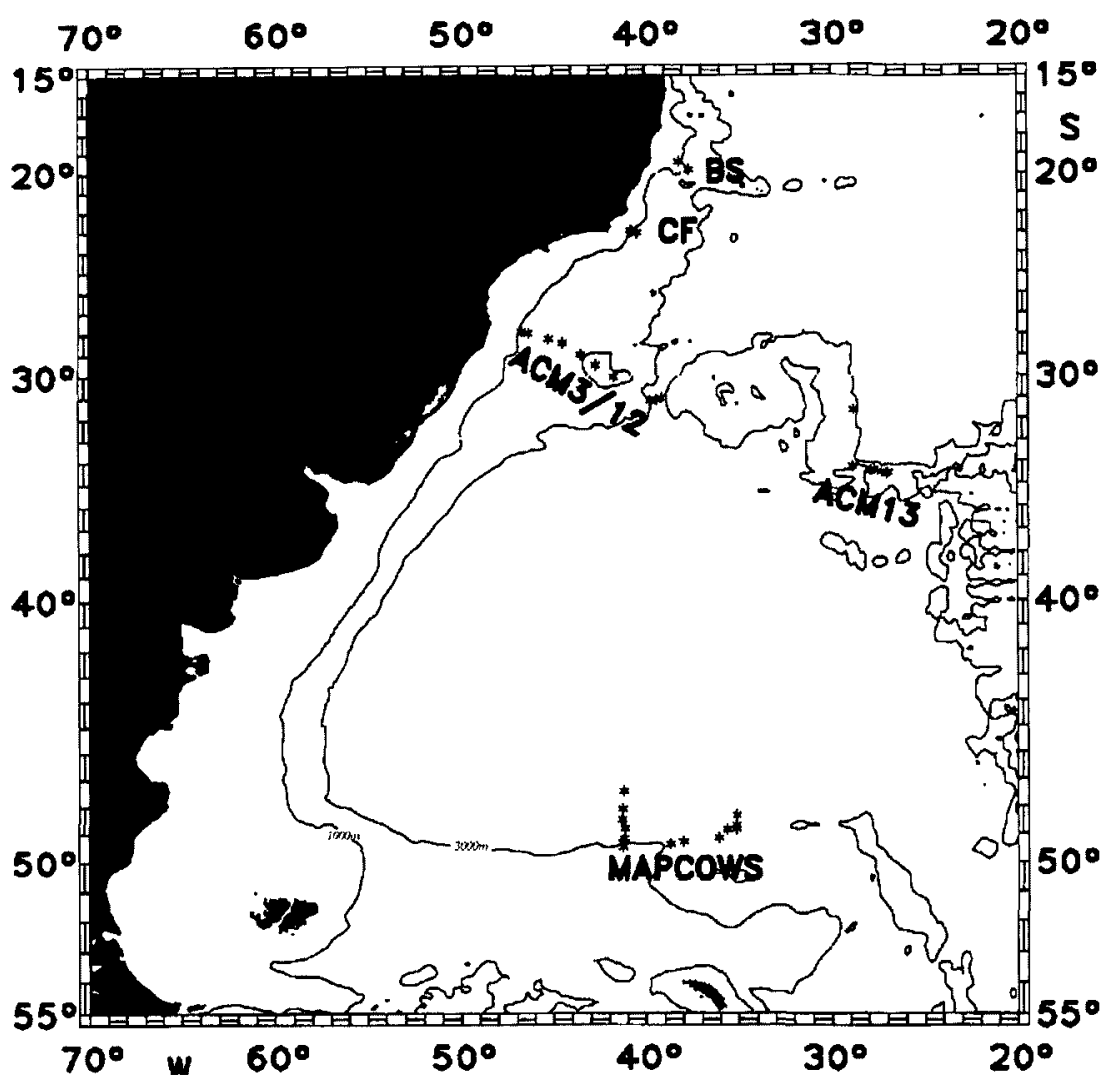

Fig. 2: Region covered by the workshop. Arrays with long-term current measurements from the boundary current system and the deep water are indicated as follows: MAPCOWS is U.S. pre-WOCE (Whitworth et al., 1991); ACM3/12 is German/U.S. WOCE (Zenk et al., 1993); ACMI3 is German WOCE (Zenk, 1994); BS and CF are Brazilian/German (Y. Ikeda and T.J. Müller, unpublished data). Note the gap along the South American Coast. 
Temporal monitoring at a few key locations could put bounds on this variability.

b) Modeling efforts

- Process studies of limited regions should be used to dissect the phenomena of interest and thereby assess the relative importance of various processes. For instance, a model tuned to the potential vorticity structure of the Santos Bight should be used to investigate meander dynamics of the Brazil Current. Results could be compared to COROAS data before proceeding with similar studies of frontal meanders in other regions such as the Brazil Current recirculation region and the Malvinas Current. Particular attention should be given to the confluence region which not only has substantial frontal interactions but also transport and entrainment of Rio de la Plata waters.

- The process models should progress in complexity towards "realistic" regional models which then provide confidence to proceed with a realistic Brazil-Argentine basin model with resolution high enough to reflect adequately the western boundary processes.

\section{2) Large-scale shelf processes}

\section{a) Observations}

- Spatial variability of subsurface properties has been surveyed only in limited areas; consequently, knowledge of large-scale variations of mesoscale activity is severely limited. The need for coordinated multiship surveys in the region between $20^{\circ}$ and $50^{\circ} \mathrm{S}$ is acute. A few such cruises resolving seasonal variability are needed to characterize the large-scale variability in a synoptic fashion. These cruises should include biological and chemical sampling efforts so that effects on local ecosystems can be assessed.

- The cruise efforts described above cannot address short timescale phenomena such as effects of cold front passages or intrusions of slope waters due to mesoscale frontal activity. Thus, temporal monitoring by moored instruments will be crucial to the effort.

\section{b) Modeling efforts}

Several process studies should be executed before a realistic model of the shelf flows can be attempted. These include the following:

- Flow variability on the Argentine shelf caused by wind and heat fluxes (e.g., what is the origin of the cold/fresh current observed on the Brazilian shelf?).

- Effects of the confluence on northward transport of shelf waters.
- Effects of the fresh outflow of the Rio de la Plata on shelf circulation.

\section{3) Deep ocean issues}

In the Brazil Basin, the results from the Deep Basin Experiment of WOCE will significantly improve our knowledge of the circulation patterns at all depths from the shelf edge to the MidAtlantic Ridge. Clearly however the Argentine Basin is much less sampled, and for both basins there is no regional model available that explains the links between them. Several important aspects of the large-scale circulation in the region must be studied and understood. Outstanding issues that should be resolved are as follows:

a) The mean velocity structures and volume transports of the Brazil and Malvinas currents and of the deeper layers. These are not well known and are fundamental to other issues.

- Current meter and hydrographic measurements should be made in the Brazil Current and deeper layers between $30^{\circ}$ and $38^{\circ} \mathrm{S}$. These would provide valuable information on absolute transport and growth rate of the Brazil Current, characteristics of the recirculation cell, mass and property fluxes in the deeper layers, and transformation of water masses in the region. Hydrographic measurements should be made during winter in the southward extension of the Brazil Current to observe the production of Subtropical Mode Water that spreads northward beneath the thermocline.

- Direct velocity measurements must be made in the main northward flow of the Malvinas Current and in deeper layers between $42^{\circ}$ and $46^{\circ} \mathrm{S}$. This current has a large barotropic component, necessitating the need for direct measurements.

- Lagrangian measurements (surface drifters and subsurface floats) made on a repeated basis would provide critical statistical information about the flow along each current and the differences of paths taken by the surface and subsurface waters once they leave the western boundary.

- ADCP measurements, underway and/or lowered, should be made during the cruises to obtain critical information about absolute current velocities, both on the continental shelf and in deep water.

b) The time-varying velocity and property fields of the Brazil and Malvinas currents. Little is known of the semiannual, annual, and interannual variability of these currents, or of how such variations are related between the two currents, to the circumpolar 
flow, and to atmospheric forcing. Likewise, little is known of changes in water mass characteristics that may take place beneath the upper mixed layer.

- The current measurements discussed above should be made over multiyear periods, and ideally they should be made simultaneously. Bottom pressure measurements are now being made across Drake Passage by the UK, and these measurements, which are expected to be collected over the next several years, could be paired with the current meter measurements for a first look at South AtlanticSouthern Ocean linkages.

- Hydrographic observations should be made on a repeat basis at key locations to identify any long-term changes in the characteristics of water carried by these two currents and the deeper flow.

c) The significance of the regional western boundary currents for the global thermohaline circulation. Two major issues in need of resolution are the impact of Brazil Current eddies on the Subantarctic Zone of the Southern Ocean and the importance of intermediate and deep waters being lost from the circumpolar flow in the region of the BrazilMalvinas Confluence.

- Resources for monitoring at sea the production of Brazil Current eddies, their sizes, property transports, paths of propagation, and rates of spin down and dispersion, are clearly inadequate. An intense, preferably multiship, one-time hydrographic survey of the eddy field should be made to gain some base-line estimates.

- Detailed studies should be made using satellite altimetry and infrared imagery. These would supply valuable statistics regarding eddy production rates, sizes, propagation, and dispersion rates.

d) Long-term changes in the volumes and characteristics of thermocline, deep and abyssal waters flowing through the western South Atlantic.

- An ideal place to monitor such changes is the Vema Channel, where 2-year, deepcurrent meter measurements have recently been made. They show a distinct pattern of warming of the northward abyssal flow (Zenk and Hogg, unpublished observations). Reinstrumenting the Vema Channel on a longer-term basis could be done relatively inexpensively and would provide critically needed information.
- Set up a time series station in the deep South Atlantic subtropical gyre similar to the Bermuda, HOT (Hawaii) and ESTOC (Canary Island) stations.

\section{Acknowledgments}

Thanks to Mrs. Maria da Conceição P. Campos, whose valuable help was instrumental during the preparation and events of the SWAP meeting. The São Paulo State funding agency (FAPESP) provided most of the financial support for the SWAP workshop (grants 94/3091-4 and 91/0542-7). Additional funds came from Conselho Nacional de Desenvolvimento Cientifico e Tecnológico $(\mathrm{CNPq})$, through the COROAS Project, and from the Oceanographic Institute of the University of São Paulo (IOUSP).

\section{References}

da Silveira, I.C.A., L.B. de Miranda and W.S. Brown, 1994: On the origins of the North Brazil Current. J. Geophys. Res., 99, 22501-22512.

Gordon. A.L., 1981: South Atlantic thermocline ventilation. Deep-Sea Res., 28, 1239-1264.

, and C.L. Greengrove, 1986: Geostrophic circulation of the Brazil-Falkland Confluence. Deep-Sea Res., 33, 573-585.

Müller, T., 1994: Direct Current Measurements in the Southwest Atlantic. In: Report of the Southwestern Atlantic Physical Oceanography Workshop, E. Campos, ed. University of São Paulo. São Paulo, Brazil, p. 18-20.

Peterson, R.G., 1992: The boundary currents in the western Argentine Basin. Deep-Sea Res., 39, 623-644. , 1994: Upper layer Circulation of the South Atlantic. In: Report of the Southwestern Atlantic Physical Oceanography Workshop. E. Campos, ed. University of São Paulo, São Paulo, Brazil, p. 43.

and L. Stramma, 1991: Upper-level circulation in the South Atlantic Ocean. Prog. Oceanogr. 26, 1-73.

and T. Whitworth III, 1989: The Subantarctic and Polar Fronts in relation to deep water masses through the southwestern Atlantic. J. Geophys. Res., 94, 10817-10838.

Piola A.R., 1994: The Shelf/Slope Front off Patagonia. In: Report of the Southwestern Atlantic Physical Oceanography Workshop. E. Campos, ed. University of São Paulo, São Paulo, Brazil, p. 48.

Reid, J.L., 1989: On the total geostrophic circulation of the South Atlantic Ocean: flow patterns, tracers and transports. Prog. Oceanogr., 23, 149-244.

Stevenson. M.R. and R.B. de Souza, 1994: Recirculation of the Brazil Current South of $20^{\circ} \mathrm{S}$. In: Report of the Southwestern Atlantic Physical Oceanography Workshop, E. Campos, ed. University of São Paulo, São Paulo, Brazil, p. 56.

Stramma. L., 1989: The Brazil Current transport south of $23 \mathrm{~S}$. Deep-Sea Res., 36, 639-646.

_. Y. Ikeda and R.G. Peterson, 1990: Geostrophic transport in the Brazil Current region north of $20 \mathrm{~S}$. Deep-Sea Res., 37, 1875-1886.

Whitworth, T. III, W.D. Nowlin, R.D. Pillsbury, M.I. Moore and R.F. Weiss, 1991: Observations of the Antarctic Circumpolar Current and Deep Boundary Current in the Southwest Atlantic. J. Geophys. Res., 96, 15105-15118.

Zemba, J.C., 1991: The Structure and Transport of the Brazil Current between 27 and 36 South. Ph.D. dissertation, Woods Hole Oceanographic Institution, $160 \mathrm{pp}$.

Zenk. W., T.J. Müller and N. Hogg, 1993: Meteor finishes her second DBE cruise. Int. WOCE Newsletter, 14 June, 1993. 1994: All current meters recovered from the Hunter Channel Array: FS METEOR finishes her third DBE cruise. Int. WOCE Newsletter, 16 July, 1994.
An intense, one-

time hydrographic

survey of the eddy

field should be

made ... . 